\title{
Attention to Rhotacism Language Problem by Oral Surgery and Vibrostimulatory Therapy - A Case Report
}

\author{
Tratamiento para el Problema del Lenguaje de Rotacismo Mediante \\ Cirugía Oral y Terapia Vibroestimulatoria - Reporte de un Caso
}

\author{
A. Nevárez-Rascon*; J. A. Medina-Lopez*; M. M. Nevárez-Rascón ${ }^{\star *}$; J. Vargas-Esquivel; \\ D. Consdtance-Cortéz*; D. A. Guzmán-Gastélum*; G. De la Torre-Morán* \& A. Donohué-Cornejo*
}

NEVÁREZ-RASCON, A.; MEDINA-LOPEZ, J. A.; NEVÁREZ-RASCÓN, M. M.; VARGAS-ESQUIVEL, J.; CONSDTANCECORTÉZ, D.; GUZMÁN-GASTÉLUM, D. A.; DE LA TORRE-MORÁN, G. \& DONOHUÉ-CORNEJO, A. Attention to Rhotacism language problem by oral surgery and vibrostimulatory therapy-a case report. Int. J. Odontostomat., 7(1):25-28, 2013.

\begin{abstract}
Ankyloglossia may prevent the tongue from contacting the anterior palate, which promotes an infantile swallow and hamper the progression to an adult-like swallow. This can result in an open bite deformity and in some cases it can be associated to mandibular prognathism and language problems like rhotacism, described as the inability or difficulty in pronouncing the sound / $\mathrm{r} /$. The surgical cut of the frenum tissue that connects the tongue to the jawbone (frenulectomy) and the language rehabilitation treatment with functional oral devices, represent an alternative treatment for this problem. An 11-year-old boy reported with language performance problems, dental malposition and diagnostic of ankyloglossia condition, received frenulectomy surgery and language rehabilitation treatment with functional oral devices during six months. Language diagnosis was carried out in three periods of time: prior to the surgery, four weeks after the surgery and six months later. Combined surgical and functional therapies proved to be a better alternative than only surgical therapy. Combined therapies increased the speech abilities as well as swallowing functions, therefore, the patient's self-esteem.
\end{abstract}

KEY WORDS: rhotacism, ankyloglossia, frenulectomy, vibrostimulation

\section{INTRODUCTION}

Ankyloglossia, known as tongue tied is a congenital oral abnormality which may decrease mobility of the tongue tip (Messner \& Lalakea, 2002); it is caused by an unusually short or thick lingual frenulum, a membrane connecting the underside of the tongue to the floor of the mouth. Ankyloglossia varies in degree of severity from mild cases characterized by mucous membrane bands, to complete ankyloglossia, whereby the tongue is tethered to the floor of the mouth (Horton et al., 1969), affecting feeding, speech, oral hygiene (Keith, 1972) and mechanical/social effects (Lalakea \& Messner, 2003). Ankyloglossia can also prevent the tongue from contacting the anterior palate, promoting an infantile swallow and hampering the progression to an adult-like swallow which can result in an open bite deformity and in some cases in mandibular prognathism. This happens when the tongue contacts the anterior portion of the mandible with exaggerated anterior thrusts (Messner \& Lalakea, 2000); such conditions have been related to language problems like rhotacism. In English, the most common occurrence of this type is a pronunciation perceived as closer to $(w)$, the wrong pronunciation of the consonant $/ \mathrm{r} /$, called rhotacism. This is more common among speakers of languages that have a trilled / rr /, such as Swedish, Finnish, Italian, Polish, and Spanish. This sound is usually the last one a child masters; some people never learn to produce it, they substitute it with other sounds, such as the velar approximant, the uvular approximant, and the uvular trill (often called "French r") (Catford, 2001). The surgical cut of the frenum tissue that connects the tongue to the jawbone is called frenulectomy (Tongue-tie surgery), a procedure through which one of the folds of tissue is removed by using scalpel or laser techniques

\footnotetext{
* Departamento de Estomatología. Instituto de Ciencias Biomédicas, Universidad Autónoma de Ciudad Juárez UACJ, Ciudad Juárez, México.

* Facultad de Odontología, Universidad Autónoma de Chihuahua, Chihuahua, México.
} 
NEVÁREZ-RASCON, A.; MEDINA-LOPEZ, J. A.; NEVÁREZ-RASCÓN, M. M.; VARGAS-ESQUIVEL, J.; CONSDTANCE-CORTÉZ, D.; GUZMÁN-GASTÉLUM, D. A.; DE LA TORRE-MORÁN, G. \& DONOHUÉ-CORNEJO, A. Attention to Rhotacism language problem by oral surgery and vibrostimulatory therapy-a case report. Int. J. Odontostomat., 7(1):25-28, 2013.

\section{CASE REPORT}

An 11-year-old boy reported with language performance problems and dental malposition. Although there was a history of previous attention through dental restorations, the patient did not receive proper attention to the language limitations. The extraoral examination was contributory to determine the ankyloglossia condition due to the heart-shaped tongue, caused by the traction of the lingual frenulum (Fig. 1). The intraoral examination revealed the presence of a short lingual frenulum. The diagnosis was a language problem characterized by disability on the articulation of certain phonemes due to the ankyloglossia condition. The patient and the parents were informed about the diagnosis and the alternatives of treatment.

The treatment plan included the surgical cut of the frenulum tongue (frenulectomy) and language rehabilitation treatment thought functional oral devices.

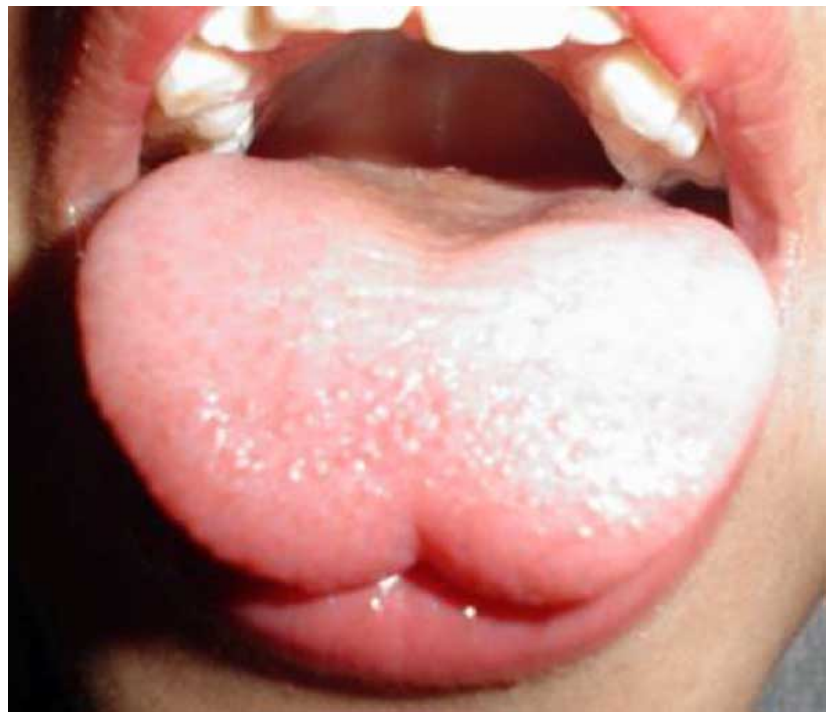

Fig. 1. Clinical aspect of the tongue showing the heart-shape originated by a short lingual frenulum.

Frenulectomy surgery. The procedure to cut partially the tissue that connects the tongue base to the jawbone was done by applying numbing shots of lidocaine. The frenum was carefully cut with a scalpel, avoiding the blood vessels. After the cut, the area opened in the shape of a diamond. The tongue was immediately freed. Finally, it was proceeded the suture of the edges (Fig. 2). Postoperative cares included prophylactic antibiotic therapy (amoxicillin/clavulanic acid 875/125 mg per $7 \mathrm{~d}$ ), a special diet free of spicy and greasy food was recommended, as well as frequents clinical observations at 24,48 and 72 hours after the surgery. After four weeks, the tissue had healed completely.

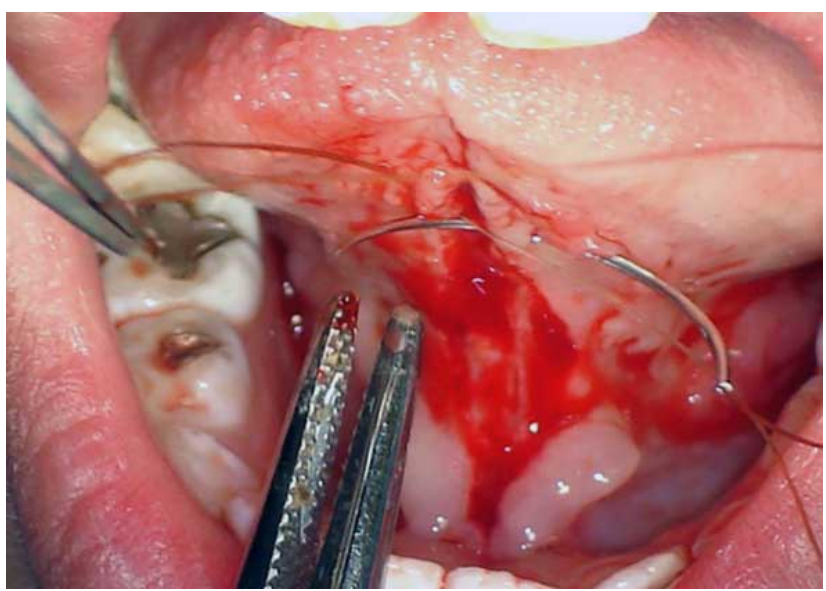

Fig. 2.Surgical cut of the frenulum tongue (Frenulectomy) and suture union of the rhomboidal walls.

Diagnosis of language. Initial language diagnosis was carried out on a speech and hearing clinic, to diagnose the articulation/phonological abilities, taking as reference different authors' investigations (Ghandour \& Kaddah, 2011; Ruscello, 2008; Powell et al., 1991; Carter \& Buck, 1985), and their methodology to diagnose language abilities and category determination. Three aspects were taken into account: Phoneme sound level, syllable level and stimulability score of the phonemes: $/ \mathrm{s} /, / \mathrm{z} /, / \mathrm{k} /, / \mathrm{g} /$ and $/ \mathrm{r} /$. Language performance was measured in three periods of time: prior to the surgery (T0), four weeks after the surgery (T1) and six months later (T2).

Language therapy. Two functional oral devices were used during the language therapy: A vibrant-stimulator, structured with an electric micro motor and a battery activated through lingual contact (patent: NL/A/2006/ $000073 \mathrm{Mx}$ ) and a rotary accessory for lingual exercises (Fig. 3). The patient received therapy in sessions of an hour, two sessions per week. The complete therapy was carried out during six months, with an excellent cooperation and disposition of the patient. In this particular case the results of the combined therapy surgical-functional were satisfactory: thepatient increased his speech abilities, improving his swallowing function and his self-esteem. His speech changed to clear and fluid by the end of the therapy. 


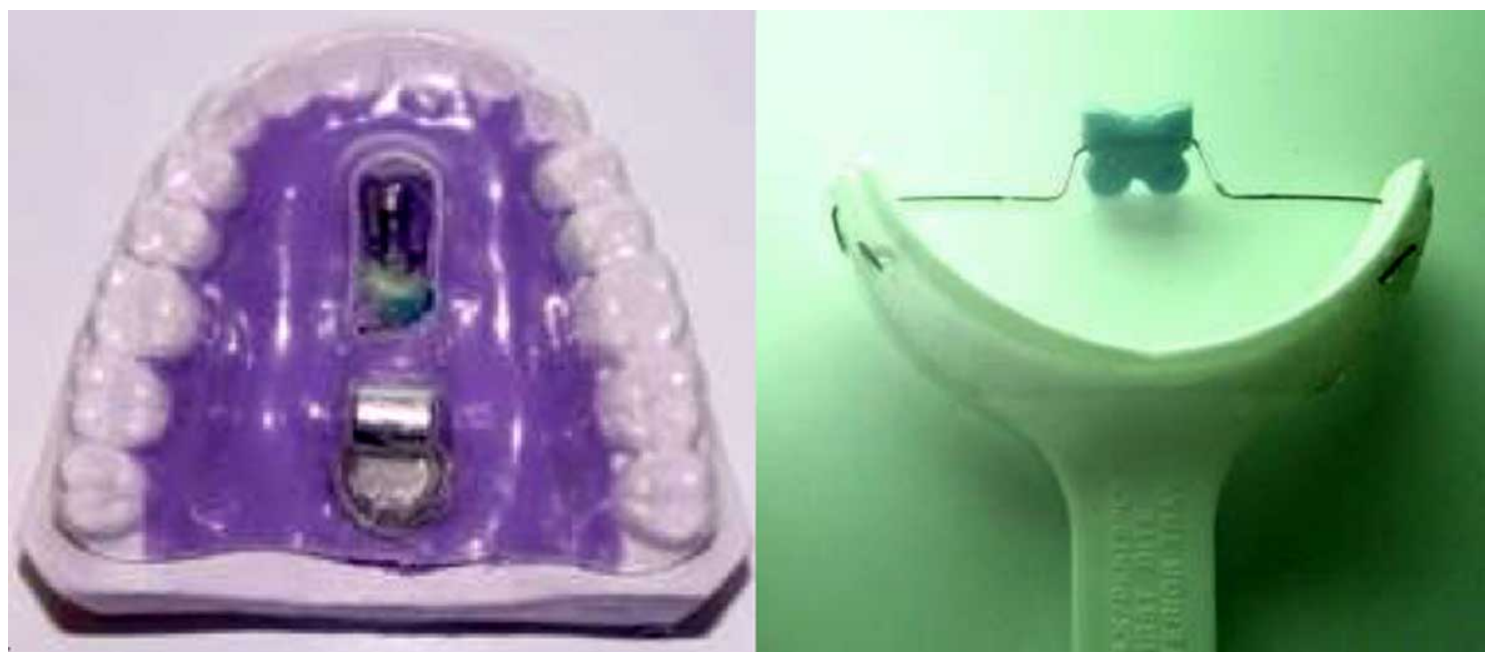

Fig. 3. Prototypes of a vibrostimulation device structured with a micro motor and accessory for lingual exercises.

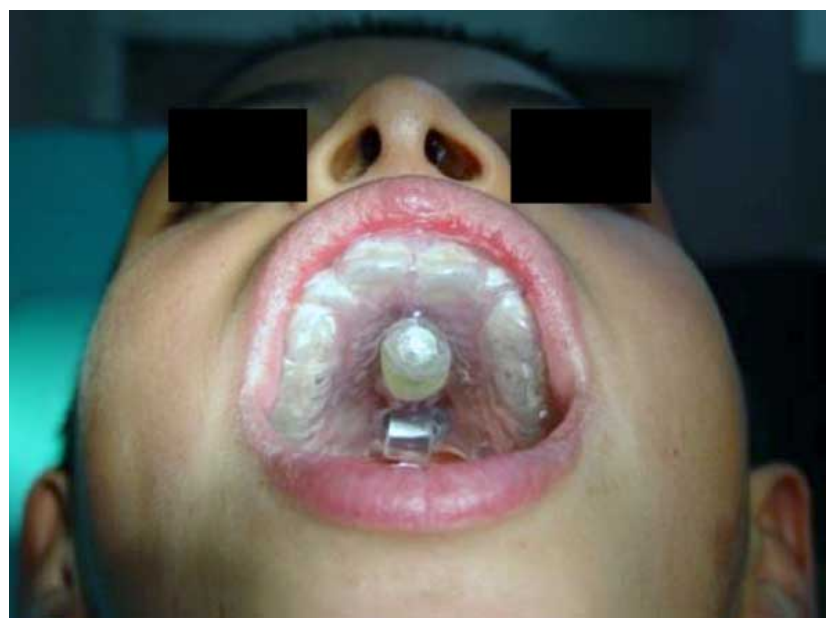

Fig. 4. Intraoral vibrostimulation device positioned.

\section{DISCUSSION}

Ankyloglossia is responsible for some articulations problems that lower speech intelligibility. Combined surgical treatment and speech-language rehabilitation achieved significant improvement of language function and abilities and expressive language. Functional therapy with intraoral vibratory devices is not harmful and simple to apply as an alternative to reinforce an integral treatment of language problems caused by ankyloglossia.

One of the risks of frenulectomy surgery carry is profuse bleeding because the tongue contains many blood vessels. Therefore lingual frenulectomies are more likely than other types of surgeries to cause a lot of bleeding or long-lasting bleeding. However, this is a quite rare complication.

The first step to establish the right treatment for this anomaly is the proper examination and the proper knowledge in order to recognize this anomaly, if the tongue does not move freely, language may not be correctly performed. A characteristic sign of ankyloglossia is the heart-shaped tongue when the patient is requested to project the tongue forward. Single frenulectomy procedure as a conventional treatment for ankyloglossia condition associated to language problems like rhotacism could be a subject of discussion because the efficient language rehabilitation may not be complete without a functional therapy, since bad habits like mispronunciation of the consonant $/ r$ / (called rhotacism). At present different methods of diagnosis are available to recognize rhotacism from simple to complex classifications (Carter \& Buck; Grigore et al., 2010), which can be procedures that use patterns of algorithms to determinate the correct pronunciations of the consonant / $\mathrm{r} /$ from impaired pronunciations. Early speech-language evaluation and oral inspection may avoid language problems; the early attention of this condition gives as a consequence better results. Surgical treatment combined with therapy of language stimulation reinforces the rehabilitation of the language. Professionals of dentistry should consider the interdisciplinary work for these cases.

The adequate treatment to these problems plays a determinant role in the socialization of children in school age. Future research is recommended determinate the efficiency of these therapies. 
NEVÁREZ-RASCON, A.; MEDINA-LOPEZ, J. A.; NEVÁREZ-RASCÓN, M. M.; VARGAS-ESQUIVEL, J.; CONSDTANCE-CORTÉZ, D.; GUZMÁN-GASTÉLUM, D. A.; DE LA TORRE-MORÁN, G. \& DONOHUÉ-CORNEJO, A. Attention to Rhotacism language problem by oral surgery and vibrostimulatory therapy-a case report. Int. J. Odontostomat., 7(1):25-28, 2013

ACKNOWLEDGEMENTS. The authors wish to express their appreciation to the Departamento de Estomatología del Instituto de Ciencias Biomédicas of the Universidad Autónoma de Ciudad Juárez UACJ and to the Facultad de Odontología de la Universidad Autónoma de Chihuahua.

NEVÁREZ-RASCON, A.; MEDINA-LOPEZ, J. A.; NEVÁREZ-RASCÓN, M. M.; VARGAS-ESQUIVEL, J.; CONSDTANCECORTÉZ, D.; GUZMÁN-GASTÉLUM, D. A.; DE LA TORRE-MORÁN, G. \& DONOHUÉ-CORNEJO, A. Tratamiento para el problema de lenguaje de rotacismo mediante cirugía oral y terapia vibroestimulatoria - reporte de un caso. Int. $J$. Odontostomat., 7(1):25-28, 2013.

RESUMEN: La anquiloglosia puede evitar que la lengua entre en contacto con la región anterior del paladar, lo que promueve una deglución infantil y dificultan la adecuada deglusión en el adulto. Esto también puede dar lugar a una mordida abierta y en algunos casos, estar asociada con prognatismo mandibular y problemas de lenguaje como el rotacismo, que se describen como la incapacidad o dificultad para pronunciar el sonido / r /. La exsición quirúrgica del tejido que conecta frenillo de la lengua a la mandíbula (frenectomía) y el tratamiento rehabilitador del lenguaje con dispositivos orales funcionales, representan una alternativa de tratamiento para este problema. Un niño de 11 años de edad, con problemas de lenguaje, malposición dental y diagnóstico de anquiloglosia, fue sometido a frenectomía y tratamiento de rehabilitación dellenguaje mediante dispositivos orales funcionales durante seis meses. El diagnóstico del lenguaje se llevó a cabo en tres periodos de tiempo: antes de la cirugía, cuatro semanas después de la cirugía y seis meses más tarde. La combinación de tratamiento quirúrgico y funcionales demostraron ser una alternativa mejor que la terapia quirúrgica por sí sola. Las terapias combinadas aumentaron la capacidad del habla, así como funciones de deglución, por lo tanto, la autoestima del paciente.

PALABRAS CLAVE: rotacismo, anquiloglosia, frenectomía, vibroestimulación.

\section{REFERENCES}

Carter, E. T. \& Buck, M. W. Prognostic testing for functional articulation disorders among children in the first grade. J. Speech Hear Disord., (23):124-33, 1985.

Catford, J. C. On Rs, rhotacism and paleophony. J. Int. Phon. Assoc., 31(2):171-85, 2001.

Ghandour, H. \& Kaddah, F. Factors affecting stimulability of erred sounds in common types of dyslalia. Egyptian Journal of Ear, Nose, Throat and Allied Sciences, 12(1):61-7, 2011.

Grigore, O.; Grigore, C. \& Velican, V. Intelligent System for Impaired. Speech Evaluation. Proceedings of the International Conference on Circuits, Systems, Signals, 10:365-8, 2010.

Horton, C. E.; Crawford, H. H.; Adamson, J. E. \& Ashbell, T. S. Tongue-tie. Cleft Palate J., 6:8-23, 1969.

Keith, R. W. Handbook of Speech Pathology and Audiology. Arch. Pediatr. Adolesc. Med., 123(3):265, 1972.

Lalakea, M. L. \& Messner, A. H. Ankyloglossia: the adolescent and adult perspective. Otolaryngol. Head Neck Surg., 128(5):746-52, 2003.

Messner, A. H. \& Lalakea, M. L. Ankyloglossia: controversies in management. Int. J. Pediatr. Otorhinolaryngol., 54(23):123-31, 2000.
Messner, A. H. \& Lalakea, M. L.The effect of ankyloglossia on speech in children. Otolaryngol. Head Neck Surg., 127(6):539-45, 2002.

Powell, T. W.; Elbert, M. \& Dinnsen, D. A. Stimulability as a factor in the phonologic generalization of misarticulating preschool children. J. Speech Hear Res., (34):1318-28, 1991.

Ruscello, D. M. Nonspeech oral motor treatment issues related to children with developmental speech sound disorders. Lang. Speech Hear Serv. Sch., 39(3):380-91, 2008.

Correspondence to:

Alfredo Nevarez-Rascon PhD

Departamento de Estomatología.

Instituto de Ciencias Biomédicas

Universidad Autónoma de Ciudad Juárez UACJ

Edificio G1 de Posgrados ICB cubículo G1 105c

Anillo envolvente PRONAF y Estocolmo s/n

C.P. 32310 Ciudad Juárez

Chihuahua

MÉXICO

Tel. 52 (656) 6881661 ext. 1363

Email- alfredonevarez@hotmail.com

Received: 14-07-2012

Accepted: 10-12-2012 